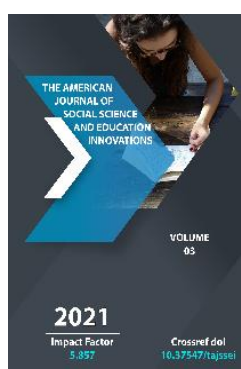

Copyright: Original content from this work may be used under the terms of the creative commons attributes 4.0 licence.

\section{Social Status And The Role Of Education In The Formation Of Patriotic Feelings}

\author{
Umidjon Makhamadjonovich Akhmatkulov \\ Lecturer Faculty Of Military Education, Fergana State University, Fergana City, Uzbekistan \\ Samariddin Alikulovich Axatov \\ Head Of The Methodical Training Cycle Of The Faculty Of Military Education Fergana State \\ University, Fergana City, Uzbekistan \\ Xakimjon Ruzibaevich Aslanov \\ Senior Lecturer Faculty Of Military Education Fergana State University, Fergana City, \\ Uzbekistan
}

\title{
ABSTRACT
}

The article states that the development, power of the nation is in harmony with the national unity of the people that make up this nation, with their cooperation activities, the sense of patriotism is one of the important aspects of understanding the sense of national unity, socio-psychological, individual psychological characteristics, feelings manifest themselves in the sense of patriotism and the formation of young people as spiritually harmonious people, finding content as a person who is always ready to serve in the interests of his motherland and nation, is one of the pressing issues of the present period.

\section{KEYWORDS}

Personal maturity, spirituality, development, national unity, society, national consciousness, cooperation, subject, national values, traditions

\section{INTRODUCTION}

The patriotism problem since olden times excites experts, because patriotism makes one of distinctive, patrimonial characteristics of society. From the first steps of person activity there was an awareness of need of the general interaction for survival. The integration 
mechanism had been developed as ideological structure. The society needs as mutual understanding uniting basis had been implemented there.

\section{MAIN PART}

The ideology organized all human and society life as unified organism, developed the expedient society action program, differentiation of mutual influence at each other. The territory and other components unity integrity understanding (language, clothes, traditions, etc.) gradually formulated in society the concept of patriotism as love to the earth, patrimonial beginning.

\section{LITERATURE REVIEW}

The analysis of existing scientific approaches in the study of problems of patriotism indicates the existence of different positions in their understanding, exactly: S.M.Kodirov, S.Nishonova, U.Makhkamov and others consider patriotism "moral principle", O.Musurmonova, Sh.A.Abdullayev, M.H.Makhmudov and others "moral category", N.P.Egorov, L.R.Bolotina, T.A.Ilyina, T.N.Malkovskaya, I.S.Marienko, Y.P.Sokolnilov, A.D.Soldatnikov and others, - "complex moral quality", G.I.Shukina - "feature of morality", I.F.Kharlamov - "set of moral feelings and traits behavior", L.I.Mishchenko - "a collection of feelings, principles, and properties", S.S.Khayrulin - "part of person's spirituality". The analysis of these approaches showed that methodological and methodical aspects of patriotic education were developed in the framework of pedagogy of general secondary education and are not sufficiently developed in higher education.

\section{RESEARCH METHODOLOGY}

Developed and existing at the present time, the theoretical foundations and models of Patriotic education are systems mainly focused on the traditional cycle of education, poorly taking into account the modern normative legal aspects of Patriotic education, youth policy and motivations of students. Current state of research is characterized by: lack of the patriotic upbringing in the institution of higher education (according to expert estimates the effects of institutions on patriotic education of youth occupies the last position after family and school); the lack of the teaching staff of clear state-value guidelines in solving pedagogical problems of Patriotic direction; the unformed educational space of patrioticoriented education of the institution of higher education, which is still a disparate elements of the system training and education, created in previous years and not yet adapted to solve new problems in the light of the new educational paradigm; weak motivational and technological readiness of teachers to patriotic and other areas of education, the lack of verified and effective technology; insufficient development of qualitative indicators to assess the formation of patriotism among students. The study raises the following questions: What model and the corresponding technology of patriotic education in the higher education students can give the best results? Does patriotism itself, as the most important unifying spiritual and practical regulator of social life, contribute to increasing the efficiency of the entire process of educating the students in the institution of higher education? 


\section{ANALYSIS AND RESULTS}

So what is 'patriotism' and who is 'a patriot'? To answer this question is quite difficult. More contemporary definition of 'patriotism' associates a person's intellect with his emotional reactions to his place of birth, upbringing, childhood and adolescent memories, and his becoming a person. Further more precise definitions of 'patriotism' and 'patriot' are provided: 1 . The main of them is to respect the place of birth and permanent residence; love and care of this territory; honoring its local traditions; eternal loyalty to this land. 2. Showing respect for ancestors, love and tolerance to the fellow-countrymen, willingness to help them, weaning them away from the bad. The highest degree of this characteristic is benevolence to all compatriots who are the citizens of this country, i.e. the awareness of social body called as 'nation of citizenship'. 3. Performing certain daily activities which benefit the country, embellishing and developing homeland, helping fellow citizens and compatriots, and providing mutual assistance to them [4]. If patriotism is expressed as one's concerns about his country's past and present, civil consciousness is related to a person's association with a certain nation and its political activity.

The term 'civil consciousness' is polysemantic:

1) Antithesis of anti-policy attitude, active and conscious involvement in political affairs;

2) Psychological sense of being a citizen and full member of political community;

3) Ability and willingness to act as a full citizen;

4) The highest virtue of free and full member of political community;
5) Commitment to political community, mostly to the state, willingness to sacrifice for nation. These and other related concepts of 'civil consciousness' complement and underpin each other; this is why it takes wider meaning, identifying internal connection and affinity of 'political activity', 'political activism', 'political participation'

The main tasks of educating young people in the spirit of patriotism are:

- Educating young people in the spirit of the national idea and devotion to the Motherland, to instill in their hearts and minds that the defense of the Motherland is an honorable and sacred duty;

our ancient history and culture, our dear Motherland a nation that fought selflessly for independence and prosperity to be proud of our heroes, to form a sense of belonging to them, to strengthen confidence in the strength and potential of our national army;

- Strengthening the understanding of the need for physically strong and spiritually mature young people in our national army, the fact that military service is a sacred duty for every citizen of Uzbekistan, as well as theoretical and practical skills in this area;

- Formation in young people of skills to approach the political and social processes taking place around us and in the world based on our national interests, ideological immunity against various internal and external threats;

- Quick and independent decision-making in any complex situation,

Education of young people with the skills of effective use of modern military equipment; 
- To be ready to defend the interests of Uzbekistan not only in the military sphere, but in all spheres of life, to be selfless for the country - to instill in the minds of young people through real-life examples and effective means.

\section{CONCLUSION}

The role of educational institutions in educating young people in the spirit of patriotism is enormous. Spiritual-educational and educational work of students of higher educational institutions in the spirit of military patriotism educational activities are carried out in cooperation with the military.

\section{REFERENCES}

1. Zhengisbek Tolen, Slushash Tulenovab, Elnura Assyltaevac, Nurken Aitymbetov(2014) Formation of civil and patriotic education of youth in Kazakhstan. Procedia - Social and Behavioral Sciences 116 ( 2014 ) 4859 4863

2. S.Uzakbayeva, Sh.Zhalgasova,

A.Beisembayeva, G.Kosherbayeva(2014) The Patriotism Education Content At The Present Stage. Procedia - Social and Behavioral Sciences 141 ( 2014 ) 675-679

3. Uzakov Asliddin Mekhritdinovich( 2019) FORMATION AND DEVELOPMENT OF PATRIOTISM AMONG STUDENTS IN THE INSTITUTION OF HIGHER EDUCATION European Journal of Research and Reflection in Educational Sciences.

4. Fielding $\mathrm{H}$. The True Patriot. The True Patriot Related Writings. Middletown, 1987. 4. Desk book on thepatriotic education of pupils. Guidance manual for school administrators, teachers, form masters, pedagogues of extended education [Text] / compilers - A.N. Vyrshchikov, M.B. Kusmartsev. M.: Globus, 2007. - 330 p.

5. BykovA.K. Cooperation between structural subdivisions of higher educational establishment in the process of formation of patriotism in students: an article of N.A. Nikolenko // News of VolgGTU. - 2014. - No. 2 (129) - P.63-67.

6. BykovA.K. Sociocultural problems of education of the Russian civil consciousness and patriotism in the educational system: an article of A.K.Bykov // Pedagogic education and science. - 2011. - No. 2. - P. 8-15.

7. The Civic Mission of schools: Report from Carnegie Corporation of New York and CIRCLE: The Center for Information and Research on Civic Learning and Engagement. -Circle and Carnegie Corporation, N.Y., 2003. - o p.

8. The Civic Mission of schools: Report from Carnegie Corporation of New York and CIRCLE: The Center for Information and Research on Civic Learning and Engagement. -Circle and Carnegie Corporation, N.Y., 2003. - o p. 9. Banks J. A. Educating citizens in a multicultural society. - New York: Teachers College Press, 2014. - 465p.

9. Campbell D.E. Why we vote: how schools and communities shape our civic life. -Princeton, NJ ; Oxford : Princeton univ. press, 2006. - 267 p. 11.

10. Karimov $U$. et al. USING NEW INFORMATION TECHNOLOGIES IN DISTANCE LEARNING SYSTEM //НОВАЯ ПРОМЫШЛЕННАЯ РЕВОЛЮЦИЯ В ЗЕРКАЛЕ 
СОВРЕМЕННОЙ НАУКИ. - 2018. - С. 9-

11.

11. Каримова, Г. Й. (2018). РОЛЬ КОНСТИТУЦИИ В ПОСТРОЕНИИ

ПРАВОВОГО ГОСУДАРСТВА И
ГРАЖДАНСКОГО ОБЩЕСТВА. Теория и практика современной науки, (2), 161-163.

12. Bloom B.S. Handbook on formative and summative evaluation of student learning / B.S. Bloom, J.T. Hastings, G.F. Madaus. - New York: McGraw-Hill, 1971. -p. 923: ill., graph 131. 